\title{
The Role of Workers' Remittances and Their Interaction with Physical and Human Capital in Stimulating Economic Growth in Jordan (1979-2015)
}

\author{
Eyad Moufaq Alkousini \\ Department of Management Sciences, Al-Rashid International Private University, Damascus, Syria
}

Email address:

alkousinieyad@gmail.com

\section{To cite this article:}

Eyad Moufaq Alkousini. The Role of Workers' Remittances and Their Interaction with Physical and Human Capital in Stimulating Economic Growth in Jordan (1979-2015). International Journal of Business and Economics Research. Vol. 9, No. 5, 2020, pp. 354-363.

doi: $10.11648 /$ j.ijber.20200905.19

Received: October 9, 2020; Accepted: October 20, 2020; Published: October 26, 2020

\begin{abstract}
The objectives of this research are diverse. First, determine the impact of workers' remittances on Jordan's economic growth during the period. The second goal in the second and third models is to determine the role of remittance in economic growth if we allow the interaction between workers' remittances and human capital and physical capital, according to the theory of endogenous growth. For this purpose, time series analysis (cointegration tests and vector error correction model) is used. Corresponding it is found that all the series representing the variables are stationary at the first difference. The results also show that there are two cointegration vectors relating the variables. Therefore, the model was estimated using vector error correction model, which showed a long-term relationship between economic growth and explanatory variables. The estimate according to the first model showed that there is a significant positive effect for each of the workers' remittances, the variables of trade openness, financial policy, and the development of the financial system. while the physical and human capital variables have significance negative impact on growth. In the second and third model, it agreed with the endogenous growth theory, that if workers 'remittances are directed towards supporting physical and human capital, the impact of workers' remittances on economic growth will increase.
\end{abstract}

Keywords: Workers' Remittances, Human Capital, Economic Growth, Physical Capital, Endogenous Growth Theory

\section{Introduction}

The inflow of workers' remittances is getting the attention of many economists and development experts not only because of its increasing size but also because of its increasing influence on building and expanding the regional and local economies of many developing countries. The total volume of official remittances to developing countries recorded in 2012 was 406 billion US dollars

This is three times more than official development assistance [24]. In many estimates, the volume of workers' remittances may exceed the declared amount due to unofficial channels. The World Bank reported that about half of all remittances worldwide are transferred through informal channels. In addition, since the start of this century, official remittances to developing countries have grown at an average annual rate of $16 \%$ [25].
Before the 1980s, the debate focused more on issues related to foreign direct investment (FDI), private debt, and official development assistance (ODA). However, since the late 1990s, international migrant remittances have become more prominent in discussions of international financial flows in addition to the other three flows [13]. The increasing interest in this source is due to the fact that it is relatively more stable than other flows and is less volatile than foreign direct investment and external debt, and this is one of the reasons why workers' remittances flows to developing countries have received a greater focus in recent times, outweighing other financial flows. Also, workers' remittances come without conditions from donors. The government can dispose of workers' remittances for any of its development programs with full control. Policy makers and some economists agree that remittances are vital to the economic activities of recipient countries because they can lead to 
poverty reduction, consumption promotion and macroeconomic stability. This belief is justified because workers' remittances in developing countries have been found positively related to family well-being, and whether workers' remittances have any role in economic growth or financial development remains a country-specific question, as it is not possible to draw a direct relationship between workers remittances and macroeconomic variables in general or Economic growth, The obvious reason behind this is that workers' remittances should be used directly for production purposes or used to support human capital in order to have a long-term impact on development. Current research has presented mixed results on the effect of workers remittances on economic growth. In general, the researches has identified more than one way to support economic growth by remittances of workers, which is (1) their effect on labor provision (2) their impact on capital accumulation and investment (3) their impact on total worker productivity (4) Its impact on human capital. Therefore, it is not easy to determine the economic consequences of workers remittances flows, because workers remittances do not only affect the economic structure, but also depend on household lifestyles and consumer or investment preferences, which may have positive or negative effects. Therefore, in terms of the sustainable impact of remittances, the question is still largely experimental.

Jordan is classified as a low and middle-income country [24], and since 2000 it has shown strong economic performance, with an average annual GDP growth of $7.5 \%$ and a doubling of its per capita GDP, but because of the economic slowdown in 2008 and the situation Unstable in the region, Jordan now faces many challenges, including fluctuations in the global oil market, high unemployment rates and reliance on remittances from Gulf countries (World Bank, 2011). Migrants from Jordan are crucial to the country's economic development, as they have always been a source of employment for oil-rich countries, despite its small population, Jordan is one of the main sources of employment in the Middle East. It is the third largest recipient of remittances in the Middle East after Egypt and Morocco. In addition, the per capita remittance share in Jordan is the highest among sources of employment in the Middle East [10] and because it represents a high percentage of total revenues. Initially, remittances accounted for more than $40 \%$ of the services balance and more than $20 \%$ of GDP at the beginning of the twenty-first century (Central Bank of Jordan, 2010). Like other developing countries, the Jordanian economy suffers from a financing gap that is widening over time, which makes it necessary for Jordan to resort to external financing sources. According to data from the World Bank, Jordan is increasingly dependent on external sources of financing, foremost among which are remittances from workers. As it reached at the beginning of the study period 520 million dollars and at the end of 5,348 million dollars, the research aims to know the importance of workers' remittance flows on the Jordanian economy and how these remittance interact with both physical capital and human capital during the period (1979-2015). This research is important as it sheds light on workers' remittances and their impact on economic growth, in addition to the interaction of human capital, physical capital, and how this interaction effect the workers remittances impact on economic growth. All of this may contribute to designing a policy in Jordan that enhances the flow of remittances, giving priority to enhancing the interaction of workers' remittances with human and physical capital, and supporting this interaction in all possible ways. Therefore, this study seeks to answer the following important question: Do workers remittances enhance economic growth in Jordan, in addition to the effect of the interaction between workers 'remittances, human capital, and physical capital in enhancing the role of workers' remittances in economic growth. In the following of the research, the theoretical and applied dimensions of workers 'remittances will be addressed in the second topic, while the status of workers' remittances in Jordan will be discussed in the third topic. As for the study model, methodology and Econometrics analysis, it is covered by the fourth topic. Finally, the findings and recommendations will be addressed in the fifth topic.

\section{Literature Review}

The relationship between remittances and economic growth in recipient countries remains a matter of dispute among scholars and policymakers, and although there is a great deal of literature on this role, the fundamental question is whether remittances affect the economic growth of recipient countries. To explain the relationship between remittances and growth, scholars discussed the best model in which to understand the mechanisms affecting growth. Opinions revolve around two ways to explain this mechanism, national accounts approach and the endogenous growth model. The national accounts approach relies on the belief that the impact of workers 'remittances on macroeconomic results is through their direct and indirect effects on the balance of payments, trade deficit, exchange rate and inflation [15]. In their view, remittances have a positive impact on the balance of payments more than other capital flows (such as financial aid, direct investment, or loans), because their use is not linked to specific investment projects with high import content, nor do they bear any interest nor have to be paid. Others argue that remittances are a constant source of foreign exchange compared to other private capital flows, and that for certain countries they exhibit an anti-cyclical character (6). For this reason, most of the literature believes that remittances influence economic growth by increasing consumption, saving, or investment, for this reason. However, several studies indicate that workers' remittances have a negative impact on economic variables such as the balance of payments, the exchange rate, inflation and exports, which leads to a rise in the real exchange rate, inflation and an increase in imports, which leads to a deficit in the balance of payments. While the second model, which is the endogenous growth model, believes that the growth of 
the gross national product depends on the total productivity of factors (technological progress), and the domestic inputs of physical capital and human capital under the assumption of constant returns [23]. A large number of documents have demonstrated that the endogenous growth model supports the following point of view: human capital development and technology diffusion enhance economic growth and development by influencing total factor productivity (TFP). For this reason, Romer claimed that the rate of factor productivity growth depends on the efficiency of a human capital, The model's main argument is that remittances can boost economic growth by increasing human capital or productivity, and an important channel for achieving this is technology diffusion [21]. In addition, Udah (2011) stated that the effect of remittances on economic growth is not a direct one, but rather a factor affecting human capital. The endogenous growth model uses factor productivity, human capital, and the interaction between human capital and remittances. This argument is that there is a positive relationship between GDP per capita and human capital, human capital and remittances, physical capital, labor, technology diffusion, and government capital expenditures on economic and social services. Remittances also improve human capital by increasing health and education resources $[3,9,11]$. In the current research we will focus on the two approaches together through variables that affect workers 'remittances in the first model, and on the second model by focusing on the mechanism of interaction between workers' remittances, human capital, physical capital and the growth mechanism, according to the endogenous growth mechanism.

\section{Remittance Inflows and Capital Accumulation}

Worker remittance flows have the potential to greatly improve the livelihoods of receiving families by easing their consumption and enabling investments in human capital and more. At the macro level in the receiving country, it facilitates economic stability, improves creditworthiness, and can attract investments to enhance economic growth and reduce poverty. Worker remittance flows can affect the rate of capital accumulation in the economy of the recipient country in several ways. Of course, the most obvious would be direct financing to increase capital accumulation, as compared to what would be observed if the recipient country's economy had to rely only on domestic sources of income to raise funds for investment. However, the impact of the remittance inflows is not limited to financing domestic investment through the additional resources that these flows provide. These capital flows may improve the creditworthiness of local investors, and large remittance flows may reduce the cost of capital to the local economy. The mechanism by which remittance flows can influence domestic capital accumulation is their effect on local macroeconomic stability. To some extent, capital inflows reduce the volatility of the local economy, and tend to reduce the risk premium required for companies to invest, making domestic investment more attractive [6]. Chami in 2010 used a large sample of remittance recipient countries to show that remittances reduced production volatility. However, in a remittance receiving economy it is not necessary to achieve all of these effects, and even if these channels are effective, their effect on growth is not necessarily positive in every case. First, due to its compensatory nature, workers' remittances are likely to receive households with a high marginal propensity to consume. Therefore, you may not target the investment directly. Second, if remittances are considered permanent remittances, they may stimulate luxury consumption rather than investment. This will have a positive effect on the well-being of the family, but it will not necessarily have a positive effect on overall economic growth. Finally, the higher the degree of economic integration with the global financial market and the more developed the domestic financial system, the less likely that remittance gains will stimulate investment by easing credit restrictions, on a aggregate level [7].

There are two main areas of concern empirically in the literature: problems of moral hazard and the effect of remittances on the prices of domestically produced goods and exchange rates. Problems of ethical risk are associated with the potential reduction in the supply of labor, the development of luxury consumption patterns, and the inability to develop a culture of savings that can enable future investment and growth. Another macro-level effect of remittance flows is their effect on exchange rates through increases in the prices of domestically produced goods. The impacts shown are reminiscent of the Dutch disease or resource boom models, Some researchers have argued that remittances can increase the consumption of non-tradable goods and the prices of domestically produced goods, reduce exports, and damage the country's competitiveness in global markets. While there is some evidence of such effects among the smaller economies, the evidence is difficult to find for the larger economies [2]. The ultimate effects of transfers on labor supply or asset accumulation, for example, not only depend on the amount of money received, but also on regularity. Households that receive remittances on a regular basis may be more able to coordinate transfers with necessary expenditures, and are thus more able to Reducing labor supply, On the contrary, households receiving irregular remittance inflows will not be able to rely on these flows to meet basic needs may be less willing to change the labor supply. Likewise, the decision to use transfers for consumption or investment may partly depend on their regularity and predictability. Households that receive remittances on a predictable basis will be better able to coordinate their daily expenditures and consumption needs with remittances. In contrast, households that receive remittances on an unexpected basis are more likely to view inflows as non-permanent and thus less likely to be included in consumption planning. As a result, they may have a greater tendency to save.

\section{Remittance Inflows and Labor Force Growth}

In the era of globalization, human capital development has become an important issue around the world. The most attractive thing is that the educated are seen as the most important assets in the information economy, the more 
talented and educated people have greater opportunities to lead the entire economy [5]. Unfortunately, due to lack of resources, developing countries cannot invest in human capital. However, workers' remittances to developing countries may help by increasing investment in education [26]. There is no comprehensive definition of the concept of human capital despite numerous attempts by experts in this field. Even the famous author Gary S. Becker, who is believed to be a pioneer in the field and won the Nobel Prize for his famous article "Human Capital" stated that spending on training, education and medical care can enhance this human capital because we cannot separate the human being from his health and / Or its values, skills and knowledge. Others such as Lucas (1988) shed light on measures of human capital based on possible spending on education. In this research, spending on education will be taken as an indicator of human capital. However, education and its impact on economic growth may differ greatly between countries due to the following three main reasons, 1) Poor institutional or governance structures may have a negative effect on human capital accumulation and this can reduce the growth of the economy in general. 2) If the supply of an educated workforce expands tremendously while the demand remains the same, the marginal returns to education may decline; 3) Decreased quality of education leads to slower growth or even no improvements in human capital. Consequently, this may have negative effects on economic growth. Here, one point can be seen as an opportunity that the additional supply of educated and skilled workforce in developing countries could migrate to advanced economies and may send their income as transfers to build their local and regional economies. In this way, remittances can aid the country's long-term development and development process. One of the channels through which remittances can affect labor inputs is labor participation. Receiving remittances is expected to have a negative impact on labor participation, as families will rely on these transfers as a source of income instead of work, which reduces participation in the labor force [7]. These remittances may have a positive impact on the workforce, as they may lead to increased spending on education and health, which leads to the rehabilitation of the existing workforce, which leads to support for growth, according to the endogenous growth model through qualifying the workforce and supporting their absorptive capacity [20].

\section{Applied Studies}

The preceding discussion demonstrates, in theory, that the effect of remittances on economic growth may be ambiguous. What about empirical evidence? In recent years, more and more literature has studied the economic impact of remittances. Stahl and Arnold show that consumptionoriented worker remittances have a positive effect on the aggregate demand multiplier [22]. Adelman and Taylor also presented evidence from Mexico to demonstrate that remittances offset part of the production losses caused by migration of highly skilled workers and the study found that for every dollar Mexico receives, its output increases by about 3\$ [1]. Likewise, Desai, Kapoor and McHale found that worker remittances brought about by migration of Indian workers exceeded the tax losses [8]. They estimated that the net financial losses caused by Indian immigration to the United States represented $0.3 \%$ to $0.6 \%$ of GDP, but the positive impact of workers' remittances on economic growth exceeded $2 \%$. Yaseen analyzed the impact of remittances on the economic growth of MENA countries, where research has shown that remittances have an impact on output growth by financing consumer demand, increasing national savings, and raising funds for domestic investment [27]. Mim and Ali analyzed the relationship between remittances and growth in the MENA region. The results showed that the most important part of remittances is consumed, and remittances can stimulate growth by encouraging the accumulation of human capital [18]. The KARAGÖZ study, on Turkey for the period 1970-2005, found that the flow of workers' remittances to Turkey has a negative statistical effect on growth [15], as does the study of Chami et al on 113 countries, the study confirmed the existence of a negative impact of workers' remittances on economic growth [7]. As for the study by Giuliano and Ruiz-Arranz on 73 countries for the period between 1975-2002, the study concluded that the relationship is not statistically significant between workers remittances and economic growth [12]. With the multiplicity of studies, results were numerous, such as a study by Nsiah, C \& Fayissa, B on 64 countries from Africa, Asia, and Latin America The study finds there is a positive relationship between remittances and economic growth across the entire group [19]. SayedAbouElseoud study of Egypt for the period between 1991-2011 to study the relationship between workers remittances and private capital formation, total exports, total imports, money supply and exchange rate, private consumption, government spending, and economic growth, the existence of a common complementarity between worker remittances and economic variables, There are also one-way causal pathways from workers remittances to private capital formation, total exports, total imports, money supply and the exchange rate, while there is a two-way causal relationship between workers' remittances and both private consumption, government spending and economic growth [16]. According to the World Bank study of 67 countries during the period between 1991-2005, the study concluded that there is a positive relationship between the ratio of total remittances to GDP and GDP growth, both when investment is included or excluded from estimates [25].

\section{Remittances of Workers in Jordan}

The Jordanian economy was greatly affected by the economic, political and social developments in the surrounding region, and this led to major changes in economic trends, taking advantage of the oil and economic boom that the Gulf Cooperation Council countries witnessed 
in the seventies of the last century, and Jordan has received foreign aid. However, this boom did not continue. In the early 1980s, oil prices and Gulf Cooperation Council revenues fell sharply, and as a result aid to Jordan decreased. This led to an increase in the government's dependence on foreign loans for its development policies, and foreign investments were not at the required level during that period, and remittances to Jordan were the basis for economic prosperity and the main source of foreign exchange reserves. The Center for Strategic Research (2012) noted that, compared to foreign aid and foreign direct investment, remittances are a relatively consistent major source of international capital flows. The Central Bank of Jordan (2014) reported that the ratio of remittances to domestic exports in 2012 was $47 \%$. The Jordanian government has recognized the economic importance of remittances. Therefore, the government has taken some measures to encourage employees to work abroad, especially in the Arab Gulf states, to increase the flow of remittances. Among these facilities, for example, the granting of public sector employees a civil service leave for a period of up to 10 years according to the Memorandum of Understanding and the bilateral agreement between the Gulf and Jordanian governments. In addition, in 2013, the government recently changed the name of the Ministry of Foreign Affairs to the Ministry of Foreign Affairs and Expatriates to reflect the increasing official interest in the importance of Jordanian citizens abroad and their important economic and social role in the country. The Institute for Migration Policy indicates that in 2012 Jordan ranked eighteenth in receiving remittances, as it accounted for $11.4 \%$ of GDP (3.6 billion US dollars in 2012), compared to $22 \%$ and fourth place in 2000. Total remittance flows to Jordan began About 600 million dollars in the first year of the 1978 study period, and it fluctuated up and down ranging from 600 million dollars in 1978 to 3510 million dollars in 2008, with an average annual growth rate of 8 per cent. The remarkable decline in remittances to Jordan in 1990 and 1991 in terms of volume and as a percentage of GDP is due to the direct return of 250,000 to 330,000 Jordanians and Palestinians to Jordan from Kuwait as a result of the Iraqi invasion in August 1990. Remittances doubled between 2000 (1,800M dollars) and 2012 (3800M dollars). In theory, remittances boost GDP growth, because remittances are an important source of income for many households in developing countries. Remittances are mainly used for daily expenses, housing construction, real estate purchases, medical care and education. Part of the transfer is to be saved and can be invested. Therefore, with the increase in the percentage of remittances in GDP, GDP growth will increase, as long as many uses of remittances form part of aggregate demand. In the second half of the eighties of the last century, when Arab workers in the Arab countries were gradually replaced by Asians in the Gulf countries and gradually returned to their countries, and this explains the decrease in the volume of remittances and their relative importance in the GDP. As of the end of 2016, Jordan ranked 23rd among the best remittance recipients in the world for the percentage of remittances to GDP, and 32nd for the volume of inward remittances in US dollars. These rankings are lower than the 2007 rankings, being 10 and 29 respectively (world bank database). Although the annual volume of remittances in US dollars has remained stable since 2008 (around 3.5-6.3 billion USD dollars), the percentage of GDP has steadily decreased (from $15.75 \%$ in 2008 to $11.16 \%$ in 2016). However, GDP transfers are a more appropriate measure of remittances. However, the Jordanian economy today suffers from unprecedented conditions, including an influx of Syrian refugees due to the war, high rates of inflation and unemployment, and the reluctance of donor countries to provide direct aid to the government budget. These economic pressures, along with government debt, which accounts for around $95 \%$ of GDP, and the growing trade deficit, require the government to take drastic measures to adjust the economic structure while optimizing the use of current capital flows.

\section{Methodology}

The current study deals with the effect of workers remittances on economic growth according to the national accounts theory and the endogenous growth theory in simulations of the Romer model (1990) and based on Borenszteina et al (1998) and Makki (2004) who relied on the endogenous growth theory, Borenszteina et al (1998) By estimating the effect of foreign direct investment on growth, while the Makki (2004) study added the trade variable to the Borenszteina et al [17]. As for the second model, the effect of the interaction between human capital and workers' remittances will be measured to find out the effect of this interaction on the effectiveness of workers 'remittances in promoting growth, according to endogenous growth theory, if the world's remittances, directed towards spending on education and health will increase the absorptive capacity of human capital And deepening its role, and if directed towards investment, as in the third model, it will lead to a deepening of the role of physical capital and the spread of technology, which leads to an increase in the effectiveness of the impact on economic growth (deepening the role of physical and human capital). Accordingly, the first model can be formulated as follows:

$$
\mathrm{GNI}=\mathrm{f}(\mathrm{RE}, \mathrm{K}, \mathrm{TRA}, \mathrm{DC}, \mathrm{H}, \mathrm{GC})
$$

Where (GNI): gross national income, (K): capital formation, (RE): workers' remittances, (L): human capital, (TRA): Trade openness, (GC): government spending, (DC): Domistic credits provided to private sector.

It must be noted that the GNI is used to express the growth variable while education spending is used to express human capital. As for government spending relative to GDP, it was used as an indicator of fiscal policy according to Makki (2004), gross fixed capital formation to GDP was used as an indicator of the investment rate, the sum of exports and imports to GDP was used as an indicator of Trade openness, and credits provided to private were used as an indicator for 
Financial development and since human capital was expressed by spending on education, it is necessary to clarify how spending on education is directed in Jordan. Table 1 shows how spending on education in Jordan is directed over five years and notes that the largest volume of spending was current spending. By up to $91 \%$, a percentage that reduces the desired benefit from spending on education, the rehabilitation of human capital.

Table 1. Education spending in the last five years in Jordan.

\begin{tabular}{lllll}
\hline $\begin{array}{l}\text { The ratio of the } \\
\text { capitalist to the total }\end{array}$ & $\begin{array}{l}\text { Capital spending on } \\
\text { education }\end{array}$ & Current ratio of total & $\begin{array}{l}\text { Current spending on } \\
\text { education }\end{array}$ & $\begin{array}{l}\text { Total spending on } \\
\text { education }\end{array}$ \\
\hline $8.65 \%$ & 74.5 & $91.35 \%$ & 786.5 & 860.9 \\
$10.06 \%$ & 107.1 & $89.94 \%$ & 957 & 1064 \\
$4.69 \%$ & 54 & $95.31 \%$ & 1098.2 & 1152.2 \\
$6.24 \%$ & 81.5 & $93.76 \%$ & 1224 & 1305.5 \\
$9.66 \%$ & 134.3 & $90.34 \%$ & 1255.7 & 1390 \\
$12.71 \%$ & 182.4 & $87.29 \%$ & 1252.2 & 1434.6 \\
$8.79 \%$ & 633.7 & $91.21 \%$ & 6573.5 & 2011 \\
\hline
\end{tabular}

Source: General Budget Department.

\section{Analysis Results}

The economic analysis of the study subject is based on time series data, and this analysis requires the estimation of the Econometrics relationships between the study variables. Accordingly, preliminary statistical tests must first be conducted to determine the appropriate method for estimating these relationships, and this includes testing the unit root for data for each time series included in the estimation of the Econometrics relationship. Table 2 refers to the results of the unit root test, as the results showed that all time series are stationary at the first degree (I (1)).

Table 2. Phillip-Perron Test Results.

\begin{tabular}{|c|c|c|c|c|c|}
\hline \multirow{2}{*}{ Variables } & \multicolumn{2}{|l|}{ Level } & \multicolumn{2}{|l|}{ 1st differ. } & \multirow{2}{*}{ Integrated } \\
\hline & Intercept & intercept and trend & Intercept & intercept and trend & \\
\hline LN (GNI) & $0.520(0.985)$ & $-1.174(0.90)$ & $-3.914(0.0049 *)$ & $-5.619(0.0003 *)$ & I (1) \\
\hline LN (DC) & $-2.55(0.11)$ & $-1.19(0.89)$ & $-3.98(0.004 *)$ & $-6.28(0.0000 *)$ & I (1) \\
\hline $\mathrm{LN}(\mathrm{K})$ & $-2.066(0.25)$ & $-2.32(0.41)$ & $-4.65(0.0007 *)$ & $-4.58\left(0.0043^{*}\right)$ & I (1) \\
\hline LN (RE) & $-1.98(0.29)$ & $-2.13(0.508)$ & $-4.89(0.0003 *)$ & $-4.81(0.0024 *)$ & I (1) \\
\hline $\mathrm{LN}(\mathrm{H})$ & $0.677(0.989)$ & -1.4150 .839 & $-5.543\left(0.0001^{*}\right)$ & $-9.982(0.0000 *)$ & I (1) \\
\hline $\mathrm{LN}(\mathrm{GC})$ & $1.430(0.998)$ & $-0.721(0.963)$ & $-3.686\left(0.0087^{*}\right)$ & $-3.881\left(0.0236^{*}\right)$ & I (1) \\
\hline LNHTR & $-0.757(0.81)$ & $-2.15(0.49)$ & $4.94(0.0003 *)$ & $-5.23(0.008)$ & I (1) \\
\hline LNKRE & $-1.91(0.32)$ & $-2.25(0.45)$ & $-5.47(0.0001 *)$ & $-5.39(0.0005 *)$ & I (1) \\
\hline
\end{tabular}

Values in parentheses represent (p-value).

The null hypothesis is accepted with a $5 \%$ probability*

\section{Cointegration test}

The unit root test results showed that all the variables are staionary at the first difference, and this indicates the possibility of a complementary relationship between the variables in the long term. Johansen test is used to demonstrate the existence of this relationship. Table 4 Shows the results of the Maximal Eigen Value Test and the Trace Test. The null hypothesis is tested that states that there is no complementary vector between these variables. These tests also show the number of co-integration vectors between the study variables.

From Table 4 it is clear that there are at least two Cointegration vectors between the variables in the Maximum Eigenvalues as well as according to the Trace Test. Based on these results, work will be done to estimate the relationship in the short and long term using the vector error correction model (VECM), but before that the number of time slowdown periods must be chosen. The most widely used Schwartz criterion in this field was used to determine them. Table 3 indicates the existence of one lags period.

Table 3. Results of choosing the number of lags periods.

\begin{tabular}{llll}
\hline Model & Lag & AIC & SC \\
\hline & 0 & -6.77 & -6.46 \\
& 1 & -13.78 & $-11.29^{*}$ \\
& 2 & $-14.78^{*}$ & -10.12 \\
\hline
\end{tabular}

Indicates the optimum time lag period*

Table 4. Johansen's results for the study models variables.

\begin{tabular}{|c|c|c|c|c|c|c|c|}
\hline \multirow{2}{*}{ Hypothesized } & \multicolumn{3}{|l|}{ Trace Test } & \multirow{2}{*}{ Hypothesized } & \multicolumn{3}{|l|}{ Max-Eigen Test } \\
\hline & Trace Statistic & Critical Value 5\% & Prob & & Max-Eigen Statistic & Critical Value 5\% & Prob \\
\hline None* & 164.47 & 125.61 & 0 & None* & 61.58 & 46.23 & 0.00 \\
\hline At most $1^{*}$ & 102.89 & 95.75 & 0.014 & At most $1 *$ & 40.05 & 40.07 & 0.05 \\
\hline At most 2 & 62.83 & 69.81 & 0.158 & At most 2 & 28.53 & 33.87 & 0.19 \\
\hline
\end{tabular}

*Reject the hypothesis of non-integration at the $5 \%$ level of significance 
Results of a vector error correction model (VECM) estimation:

The results of the Johansen test for cointegration indicated that there is an integration between the variables in the long term, and therefore this relationship will be estimated through the vector error correction model (VECM). To estimate this model, the model was formulated in equation (2) in the following linear logarithmic form:

$$
\Delta L N(G N I)_{t}=\alpha_{0}+\sum_{j=1}^{n} \alpha_{j} \Delta \ln (G N I)_{t-i}+\sum_{i=0}^{m} \alpha_{i} \Delta \ln X_{t-1}+\Psi E C T_{1}+U_{t}
$$

Where GNI denotes gross national income, Xt represents the explanatory variables which are credit to the private sector (DC), trade openness (TR), domestic investment (K), human capital (L), government spending (GC), workers remittances (RE). As for $\mathrm{LN}$, it is the natural logarithm, $\Delta$ represents the first difference, ECT is the error correction factor, and its coefficient represents the ratio of errors that are corrected in each time period, and thus it shows how quickly the dependent variable adapts in the short term to its value In the long term, we consider the relationship of the dependent variable to the explanatory variables. This requires that be negative and statistically significant. Table 5 shows the results of estimating the vector error correction model (VECM) using only one time lag period. Given the results of estimating the vector error correction model (VECM), there is a long-term relationship between the economic growth variable and the explanatory variables, as the estimation of the error correction factor coefficient was negative and statistically significant. This estimate $(-0.13 \%)$ indicates that economic growth needs about Seven and a half years to return to the long-term equilibrium position, taking into account the relationship of growth with the explanatory variables.

Table 5. Results of estimating the causal relationship in the long and short term using the vector error correction model (VECM).

\begin{tabular}{|c|c|c|c|c|c|c|c|}
\hline Cointegrating Eq: & LNGNI (-1) & LNDC (-1) & LNGC (-1) & LNK (-1) & LNL (-1) & LNRE (-1) & LNTR (-1) \\
\hline CointEq1 & 1.00 & $-0.98(-1.78)$ & $-3.07(-5.016)$ & $2.16(4.9)$ & $1.72(3.12)$ & $-1.19(-4.83)$ & $-5.48(-8.10)$ \\
\hline $\mathrm{c}$ & 50.19 & ECT & $-0.13(-4.12)$ & & & & \\
\hline Cointegrating Eq: & D (LNGNI (-1)) & D (LNDC (-1)) & D (LNGC (-1)) & D (LNK (-1)) & D (LNL (-1)) & D (LNRE (-1)) & D (LNTR (-1)) \\
\hline CointEq1 & $0.29(0.95)$ & $0.24(1.82)$ & $-0.32(-1.19)$ & $0.1(0.69)$ & $0.18(1.25)$ & $0.039(0.35)$ & $-0.55(-2.46)$ \\
\hline
\end{tabular}

R-squared: 0.48, Adjusted R-squared: 0.33, SC: -10.73, AIC: -13.84, F-statistic: 3.11.

As for the model estimates in the long term, they were statistically significant at the level of $5 \%$, and this indicates the existence of a causal relationship moving from the explanatory variables to the dependent variable (GNI). The integral vector can be written in the form of an equation that shows the long-term equilibrium relationship between the variables in the model as follows:

$$
\text { LnGNI }(-1)=-50.19+0.98 \operatorname{LnDC}(-1)+3.07 \operatorname{LnGC}(-1)-2.16 \operatorname{LnK}(-1)-1.72 \operatorname{LnH}(-1)+1.19 \operatorname{LnRE}(-1)+5.48 \operatorname{LnTR}(-1)
$$

Equation No. (3) and Table 5 show the effect of the explanatory variables on economic growth. It is noticed that all the explanatory variables are statistically significant at the level of 5\% and noted the positive impact of the variable of workers' remittances and government spending expressing the fiscal policy in addition to the positive impact of trade openness and credit granted to the private sector, which reflects the development of the financial system, while the negative and statistically significant effect of each spending on education that reflects human capital, as well as the negative impact of domestic investment factors.

The results show that in view of the development of the financial system and the positive impact of government fiscal policy and its positive impact on economic growth, the positive impact of workers' remittances on economic growth supports trade opening. Workers' remittances have an impact on economic growth, while domestic investment and human capital have a negative impact on economic growth. The reason may be, as mentioned within the theoretical framework, that the more the financial system develops, the less the workers' remittances will play a role in stimulating investment by reducing credit restrictions. It may be the cause and development of luxury consumption patterns, and the inability to develop a culture of savings that could use investments and growth in the future. Remittances can also increase the consumption of non-tradable goods and the prices of locally produced goods. As mentioned previously, this evidence was found by some economists In small economies, Jordan is classified within these countries. This is in addition to the basis of the endogenous growth theory that was mentioned. the impact based on productivity factors, which is based on qualified human capital. This was not achieved in Jordan by the negative impact of human capital on economics growth. All of these factors led to the negative impact of physical capital in the long run. The results also indicate that Human capital (measured by spending on education) has not played the required role in supporting growth, and this may be due to the lack of directing spending in a way that supports absorptive capacity and improves the quality of education outcomes and focuses on quantity rather than quality. The matter that was indicated according to Table 1, which shows that the percentage directed to capital spending within the education sector does not exceed $9 \%$ of the total spending on education, which is a low percentage that does not help in enhancing absorptive capacity, and thus economic growth. The second and third model will be to 
show if workers remittances are directed towards supporting physical and human capital and how will this increase the positive impact of remittances on economic growth. that will be by adding an interaction variable between workers 'remittances and human capital in the second model and an interaction between physical capital And workers remittances in the third model.

\section{Diagnostic tests}

Diagnostic tests are carried out in order to ensure the quality of the model used for analysis and that it is completely free from Econometrics problems. Table 6 shows the results of these tests. It is noted that the Normality of Residuals Test has a probability value of 0.83 , which means that the null hypothesis cannot be rejected that states that the residuals of the model are normally distributed. As for the Serial Correlation test between the random errors, the results of the estimation showed that the probability value of the test is 0.18 , indicating that there is no serial correlation between the errors. As for the heteroskedasticity test, the probability value of the test in the model was $(0.29)$ and it is not statistically significant, and therefore it can be concluded that there is no difference in the variance of random errors.

Table 6. Diagnostic tests

\begin{tabular}{|c|c|c|c|c|c|}
\hline \multicolumn{2}{|c|}{ Normality Test } & \multicolumn{2}{|c|}{ Heteroskedasticity Test } & \multicolumn{2}{|c|}{ Serial Correlation Test } \\
\hline Jarque-bera & Prob. & F-statistic & Prob. & F-statistic & Prob. \\
\hline 0.37 & 0.83 & 1.28 & 0.29 & 1.88 & 0.18 \\
\hline
\end{tabular}

The second model:

To find out the effect of the interaction of workers 'remittances and human capital on the effectiveness of workers' remittances on economic growth, we will replace the human capital variable with a variable multiplying the human capital variable with workers 'remittances so that this last variable represents the outcome of the interaction of both variables. Results of a vector error correction model (VECM) estimation: From Table 7, the integral vector can be written in the form of an equation showing the long-term equilibrium relationship between the variables in the model as follows:

$$
\text { LnGNI }(-1)=-50.19+0.98 \operatorname{LnDC}(-1)+3.07 \operatorname{LnGC}(-1)-2.16 \operatorname{LnK}(-1)-1.72 \operatorname{LnHRE}(-1)+2.91 \operatorname{LnRE}(-1)+5.48 \operatorname{LnTR}(-1)
$$

Table 7. Results of estimating the causal relationship in the long and short term using the vector error correction model (VECM) the second model.

\begin{tabular}{|c|c|c|c|c|c|c|c|}
\hline Cointegrating Eq: & LNGNI (-1) & LNDC (-1) & LNGC (-1) & LNK (-1) & LNLRE (-1) & LNRE (-1) & LNTR (-1) \\
\hline $\begin{array}{l}\text { CointEq1 } \\
\text { c }\end{array}$ & $\begin{array}{l}1.00 \\
50.19\end{array}$ & $\begin{array}{l}-0.98(-1.78) \\
\text { ECT }\end{array}$ & $\begin{array}{l}-3.07(-5.016) \\
-0.13(-4.12)\end{array}$ & $2.16(4.9)$ & $1.72(3.12)$ & $-2.91(-5.21)$ & $-5.48(-8.10)$ \\
\hline Cointegrating Eq: & D (LNGNI (-1)) & $\begin{array}{l}\text { D (LNDC (- } \\
1))\end{array}$ & $\mathrm{D}(\operatorname{LNGC}(-1))$ & D (LNK (-1)) & D (LNLRE (-1)) & D (LNRE (-1)) & $\begin{array}{l}\text { D (LNTR (- } \\
1))\end{array}$ \\
\hline CointEq1 & $0.29(0.95)$ & $0.24(0.87)$ & $-0.32(-1.19)$ & $0.1(0.69)$ & $0.18(1.25)$ & $-0.22(-1.19)$ & $-0.55(-2.46)$ \\
\hline
\end{tabular}

R-squared: 0.48, Adjusted R-squared: 0.33, SC: -10.73, AIC: -13.84, F-statistic: 3.11

From equation No. (3) and (4) we can compare the effect of the interaction between human capital and workers 'remittances, where by comparing the impact of workers' remittances in the two models, we have the following illustrated in Table 8

Table 8 Compare between first model and second model.

\begin{tabular}{llll}
\hline The difference & second model & first model & Variable \\
\hline 1.72 & 2.91 & 1.19 & workers' remittances \\
\hline
\end{tabular}

It is noticed when adding the variable of interaction between human capital and workers 'remittances an increase in the impact of workers' remittances on economic growth, which supports the endogenous growth theory. Based on remittances if directed to support the absorptive capacity of human capital by spending it on health and education will lead to an increase in its impact on economic growth, "deepening the role of human capital" by supporting the absorptive capacity of human capital

The third model:
To find out the effect of the interaction of workers 'remittances and physical capital on the effectiveness of workers' remittances on economic growth, we will replace the physical capital variable with a variable multiplying the physical capital variable with workers 'remittances so that this last variable represents the outcome of the interaction of both variables. Results of a vector error correction model (VECM) estimation: From Table 9, the integral vector can be written in the form of an equation showing the long-term equilibrium relationship between the variables in the model as follows:

$$
\text { LnGNI (-1)=-50.19+0.98LnDC (-1)+3.07LnGC (-1)-2.16LnKRE (-1)-1.72LnH (-1)+3.36LnRE (-1)+5.48LnTR (-1) }
$$

Table 9 Results of estimating the causal relationship in the long and short term using the vector error correction model (VECM) the third model.

\begin{tabular}{llllllll}
\hline Cointegrating Eq: & LNGNI (-1) & LNDC (-1) & LNGC (-1) & LNKRE (-1) & LNL (-1) & LNRE (-1) & LNTR (-1) \\
\hline CointEq1 & 1.00 & $-0.98(-1.78)$ & $-3.07(-5.016)$ & $2.16(4.9)$ & $1.72(3.12)$ & $-3.36(-6.27)$ & $-5.48(-8.10)$ \\
c & 50.19 & ECT & $-0.13(-4.12)$ & & & & \\
\hline
\end{tabular}




\begin{tabular}{llllllll}
\hline Cointegrating Eq: & LNGNI (-1) & LNDC (-1) & LNGC (-1) & LNKRE (-1) & LNL (-1) & LNRE (-1) & LNTR (-1) \\
\hline Cointegrating Eq: & D (LNGNI (-1)) & D (LNDC (- & D (LNGC (-1)) & D (LNKRE (-1)) & D (LNL (-1)) & D (LNRE (-1)) & D (LNTR (- \\
CointEq1 & $0.29(0.95)$ & $0.24(0.87)$ & $-0.32(-1.19)$ & $0.1(0.69)$ & $0.18(1.25)$ & $-0.14(-0.67)$ & $-0.55(-2.46)$ \\
\hline
\end{tabular}

R-squared: 0.48, Adjusted R-squared: 0.33, SC: -10.73, AIC: -13.84, F-statistic: 3.11.

From equation No. (3) and (5) we can compare the effect of the interaction between physical capital and workers 'remittances, where by comparing the impact of workers' remittances in the two models, we have the following illustrated in Table 10.

Table 10. Compare between first model and third model.

\begin{tabular}{llll}
\hline The difference & third model & first model & Variable \\
\hline 2.17 & 3.36 & 1.19 & workers' remittances \\
\hline
\end{tabular}

When adding the variable of interaction between physical capital and workers 'remittances we noticed an increase in the impact of workers' remittances on economic growth, which supports the endogenous growth theory. So if workers 'remittances are directed in a way that supports the role of capital, the impact of workers' remittances on economic growth will increase. This is due to the transfer of modern methods of management, technology and training, and thus "deepening the role of capital" by increasing the physical and human productive capacities.

\section{Conclusions}

Workers' remittances are considered one of the best external flows because they are relatively stable in addition to being low in cost and not linked to any compulsory directives towards specific projects or importing specific resources.

The relative importance and significance of remittances seem to support Jordan's economic growth and Variables such as trade openness, financial development and fiscal policy contribute to this positive impact.

A negative impact of the physical capital variable has emerged, and the negative impact may be due to the positive impact of financial development in Jordan, as the more the financial system develops in the economies, the smaller the role of workers 'remittances in stimulating investment by reducing credit restrictions. The negative impact may be due to workers' remittances stimulating leisure consumption patterns, and the inability to develop a savings culture that can enable investments and growth in the future. Remittances can also increase the consumption of nontradable goods and the prices of locally produced goods.

The results showed a negative impact of human capital, represented by spending on education. It is noted that only $9 \%$ of this spending was directed towards capital spending, while the rest was directed towards current expenditures.

The results of the Error Correction Model showed that the error correction factor (speed of adjustment) is negative and has statistical significance, which indicates that economic growth in Jordan is affected by the explanatory variables used in the model in the long term. The speed of adjustment in economic growth to long-term equilibrium has reached (0.13 ), meaning that economic growth needs about 7 and a half years to return to equilibrium through its relationship with the independent variables of the model.

The study shows that workers 'remittances are important for enhancing the absorptive capacity of human capital, and if human capital interaction variables and workers remittances are included in the model (if workers' remittances are used to support human capital), they increase the positive impact of remittances on economic growth.

The study demonstrates the importance of workers 'remittances in deepening the role of physical capital and increasing productivity, and if the variables of physical capital interaction and workers' remittances are included in the model (if workers 'remittances are used to support physical capital), this increase the positive impact of workers' remittances on Economic growth.

\section{References}

[1] Adelman, I., and Taylor, J. E. (1990), 'Is Structural Adjustment with a Human Face Possible? The Case of Mexico,' Journal of Development Studies, 26, 387-407.

[2] Amuedo-Dorantes, C. and Pozo, S. (2004). Workers' remittances and the real exchange rate: A paradox of gifts. World development, 32 (8), 1407-1417.

[3] Amuedo-Dorantes, C., Georges, A., \& Pozo, S. (2008). Migration, remittances, and children's schooling in Haiti. The Annals of the American Academy of Political and Social Science, 630 (1), 224-244.

[4] Barajas, A., Chami, R., Fullenkamp, C., Gapen, M. T. and Montiel, P. (2009). Do workers' remittances promote economic growth? IMF Working Paper No. 09/153.

[5] Becker, S. G. 1993. Human capital: A Theoretical and Empirical Analysis with Special References to Education. National Bureau of Economic research. University of Chicago Press, Chicago, USA.

[6] Buch, C., Kuckulenz, A., \& Le Manchec, M. (2002). Worker remittances and capital flows. Kiel working paper no. 1130. Kiel: Kiel Institute for World Economics.

[7] Chami, R., Barajas, A., Garg, A. and Fullenkamp, C. (2010a). The global financial crisis and workers' remittances to Africa: What's the damage? IMF Working Paper No. 10/24. 
[8] Desai, M., Kapoor, D., and McHale, J. (2001), 'The Fiscal Impact of the Brain Drain: Indian Emigration to the U. S.,' Weekly Political Economy Discussion Paper, Harvard University. www.wcfia.harvard.edu/ seminars/pegroup.

[9] Edwards, A. C., \& Ureta, M. (2003). International migration, remittances, and schooling: Evidence from El Salvador. Journal of Development Economics, 72 (2), 429-461.

[10] El-Sakka, M. I. T.,(2007), "Migrant Workers" Remittances and Macroeconomic Policy in Jordan", Arab Journal of Administrative Sciences.

[11] Gitter, S. R., \& Barham, B. L. (2007). Credit, natural disasters, coffee, and educational attainment in rural Honduras. World Development, 35 (3), 498-511.

[12] Giuliano P, Ruiz-Arranz M (2005), Remittances, Financial Development, and Growth, IMF Working Paper 05/234.

[13] Gupta, S., Pattillo, C. A. andWagh, S. (2009). Effect of remittances on poverty and financial development in SubSaharan Africa. World development, 37 (1), 104-115.

[14] KARAGÖZ (2009), Workers remittances and economic growth:evidence from Turkey, Journal of Yasar University, 4 (13), pp.1891-1908.

[15] Kireyev, M. A. (2006). The macroeconomics of remittances: The case of Tajikistan. IMF working papers no 06/2. Washington: DC. International Monetary Fund.

[16] M. SayedAbouElseoud (2014), Do Workers' Remittances Matter for the Egyptian Economy, International Journal of Applied Operational Research Vol. 4, No. 1, pp. 1-26.

[17] Makki, S. (2004)."Impact of Foreign Direct Investment and Trade on Economic Growth", American Journal of Agricultural Economics vol. 86, issue 3, 795-801.
[18] Mim, Sami and Mohamed Ali (2012). Through Which Channels Can Remittances Spur Economic Growth in MENA Countries? Economics, 6: 2012-33.

[19] Nsiah, C., \&Fayissa, B. (2011). Remittances and economic growth in Africa, Asia, and Latin American-Caribbean countries: a panel unit root and panel cointegration analysis. Journal of Economics and Finance, 1-18.

[20] Perkins, D., Radelet, S., Snodgrass, D., Gillis, M., and Romer, M. (2001), Economics of Development (5th ed.), New York: W. W. Norton \& Company.

[21] Romer, P. M. (1990). Endogenous technological change. Journal of Political Economy, 98 (5, Part 2), S71-S102.

[22] Stahl, C., and Arnold, F. (1986), 'Overseas Workers' Remittances in Asian Development,' International Migration Review, 20, 4, 899-925.

[23] Udah, E. B. (2011). Remittances, human capital and economic performance in Nigeria International Journal of Human Development and Sustainability, 4 (1), 103-117.

[24] World Bank (2011) “Country Brief".

[25] World Bank, Global Economic Prospects (2006), Economic Implications of Remittances and Migration, World Bank; Washington D. C.

[26] Yang, D. (2008). International Migration, Remittances and Household Investment: Evidence from Philippine Migrants' Exchange Rate Shocks. The Economic Journal 118: 591-630.

[27] Yaseen, Hadeel (2012). The Positive and Negative Impact of Remittances on Economic Growth in MENA Countries. The Journal of International Management Studies, 7: 7-14. 